\title{
Genotyping of Hepatitis C Virus (HCV) in Infected Patients from Yemen
}

\author{
Hassan A. Al-Shamahy ${ }^{1}$, Sami Sultan Ahmed Abdu²
}

${ }^{1}$ Department of Medical Microbiology, Faculty of Medicine and Health Sciences, Sana'a University.

${ }^{2} \mathrm{Al}$-Awalagy Medical Laboratory.

Eur J Basic Med Sci 2013;3(4): 78-82

Received: 12-08-2013

Accepted: 06-02-2014

Correspondence (Yazıșma Adresi): Prof. Dr. Hassan A. Al-Shamahy P.O. Box 775 Sana'a -Yemen Tel.: +967-1-239551

E-mail: shmahe@yemen.net.ye

\begin{abstract}
Hepatitis $C$ virus has been considered to be one of the most important devastating causes of chronic hepatitis, cirrhosis, and hepatic cellular carcinoma. In this area, the epidemiology of hepatitis $C$ is not well understandable in spite it was found to be endemic in Yemen. The distribution of hepatitis $C$ virus (HCV) genotypes in the Yemen is unknown, so a molecular study was carried to investigate the prevalence of Hepatitis $C$ virus (HCV) genotypes in $\mathrm{HCV}$ infected population of Sana'a, Yemen. A total of $502 \mathrm{HCV}$-positive clinical specimens (serum, EDTA plasma) with viral loads above 2,000 IU/ml were collected for genotyping. Genotyping of 502 samples revealed four different genotypes including 1 (1a and $1 b$ ), 2a, 3 (3a) and 4. The most prevalent genotype was 4 with rate of $63.7 \%$ followed by genotype $1 a+1 b$ (26.9\%), $2 a(7.6 \%)$ and $3 a(1.8 \%)$. Genotypes 5 and 6 were not found in our patients. The predominance of $\mathrm{HCV}$ genotype 4 in our population confirms the predominance of HCV genotype 4 in Yemen and similar to most of the Arab countries in the Middle East.
\end{abstract}

Key Words: Genotypes, Hepatitis C virus (HCV), Sana'a, Yemen

\section{Yemendeki Enfekte Hastalarda Hepatit C virüs (HCV) Gen Tiplemesi}

\section{ÖZET}

Kronik hepatit, siroz ve hepato-selüler karsinomanın en önemli tahrip edici nedenlerinden birinin Hepatit C virüsü olduğu düşünülmektedir. Yemen'de endemik olarak bulunmasına rağmen, hepatit C'nin epidemiyolojisi bu bölgede iyi anlașılmamıștır. Yemen'de hepatit $C$ virüsü (HCV) genotip dağılımı bilinmiyor, bu yüzden Yemen'in Sana kentindeki HCV ile enfekte nüfusta Hepatit C virüsü $(H C V)$ genotiplerinin prevalansını araștırmak amacıyla, bu moleküler çalıșma gerçekleștirilmiştir. Viral yükleri 2,000 IU/ml'nin üzerinde olan, toplam 502-HCV pozitif klinik örnek (serum, EDTA plazma) gen tiplemesi için toplanmıștır. 502 numunenin, dört farklı gen tipini de [1 (1a ve 1b), 2a, 3 (3a) ve 4] içeren gen tiplemesi saptandı. En yaygın genotip 4 (\% 63.7) olup, bunu $1 a$ $+1 b$ (\% 26.9), $2 a$ (\% 7.6) ve $3 a$ (\% 1.8) gen tipleri izlemekteydi. Hastalarımızda 5 ve 6 gen tipleri bulunmadı. Popülasyonumuzdaki HCV genotip 4 baskınlığı, 
Yemen'deki HCV genotip 4'ün baskınlığını ve Ortadoğu'daki çoğu Arap ülkesindeki benzerliği doğrulamaktadır.

Anahtar kelimeler: Gen tiplemesi, Hepatit C virüsü $(\mathrm{HCV})$, Sana, Yemen

\section{INTRODUCTION}

Hepatitis $\mathrm{C}$ virus (HCV) infection is a global public health problem. World Health Organization (WHO) estimates up to $3 \%$ of the world's population to be infected with HCV and there are approximately 180 million individuals are thought to be infected. On average, $80 \%$ of acutely infected individuals develop a chronic infection $(1,2)$. HCV has a positive-sense single stranded RNA genome of flavivirus and about $9.6 \mathrm{~kb}$ containing one long open reading frame (ORF) with untranslated regions at both ends (3). So far, six major genotypes (HCV-1 to HCV-6) have been described, each containing multiple subtypes (for example, $1 \mathrm{a}, 1 \mathrm{~b}$, etc.) $(4,5)$. The genotype of the HCV strain appears to be an important determinant of the severity and aggressiveness of liver infection, as well as patient response to antiviral therapy $(6,7)$. HCV genotypes display significant differences in their global distribution and prevalence, making genotyping a useful method for determining the source of HCV transmission in an infected localized population $(8,9)$. HCV genotype 1,2 and 3 are distributed worldwide and their relative prevalence varies from one geographic area to another, whereas genotype 4 is predominantly prevalent in the Middle East and Africa, genotype 5 in South Africa and genotype 6 in South East Asia $(5,6,10-12)$. According to several studies, genotype 4 is predominant in Egypt, Saudi Arabia, 4 and 1 in Kuwait and Syria, and genotype 1 in Lebanon, Iraq and Iran (13-17). Yemen shows an intermediate endemicity for HCV. Several studies from the end of 1990 and early 2000 found a low rate of endemicity for $\mathrm{HCV}$, with $0.5 \%$ to $2 \%$ of blood donors from Sana'a and Aden and among an ethnically African group living in Sana'a (5\%) and on the island of Soqotra (5\%) (18). By 2010, the prevalence of HCV infection in general population had declined to $1 \%$ or less (19). Blood donor results have also shown a steady decrease in HCV infection in which the prevalence declined from $5 \%$ in $2002(18,20)$ to $1.3 \%$ in $2012(19)$. Since HCV infection among children in Yemen is rare, inter-family and sexual transmission is very low, but one should consider other factors that could contribute to the continuing transmission of HCV among the Yemeni popu- lation. Among the possible factors are blood transfusion, history of surgery and non-adherence to universal infection control precautions in medical services like hemodialysis in which high rate of HCV was reported (62.7\%) (21) and dental clinics, sharing of needles and folk medical practices like cautery and bloodletting $(19,22)$. On the other hand HCV genotype prevalence rate and the role of this agent in acute and chronic liver disease and genotype response to treatment in Yemen is absent or at least poorly understood, so this study was carried out as the first study to detected the genotype prevalence rate of HCV and response to treatment in Yemen (published elsewhere).

\section{MATERIALS AND METHODS}

This was a laboratory descriptive study conducted from January 2008 to December 2012 from different hospitals as well as polyclinics at Al-Awalagy Medical laboratory. Sana'a, Yemen. The latter is a reference laboratory serving a number of hospitals and polyclinics in Sana'a. Serum samples were collected from 502 consecutive patients with varying grades of liver diseases, high alanine transferase (ALT) for $>6$ months, and positive HCV. Patients positive for anti-HCV antibodies were referred to the reference laboratory for detection of HCV RNA level and for genotyping. The study was designed to include patient's demographics (age, sex and locations) as well. Detection of HCV ribonucleic acid (RNA) was carried out

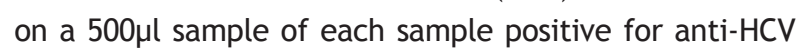
antibodies by both HCV enzyme immunoassay (EIA) and recombinant immunoblot assay (RIBA), using a commercial polymerase chain reaction (PCR) -based test (Taqman amplicor, Roche, USA) and following manufacturer's instructions. Internal control supplied by the manufacturer was added to each specimen, as an extraction and amplification control. HCV positive clinical specimens (serum, ethylenediaminetetraacetic acid) (EDTA) plasma with viral loads $>2,000 \mathrm{IU} / \mathrm{ml}$ were selected for genotyping using Versant HCV genotype assay (LiPA) 2.0 (Innogenetics, Siemens Healthcare Diagnostics, USA). This kit allows an improved and more accurate distinction between HCV genotype 1 and subtypes c to l of genotype 6 as well as between subtypes $a$ and $b$ of genotype 1 .

Data was analyzed using EPI Info -6 version. A p value of $<0.5$ was considered significant for statistical analysis. 
Table 1. The age and sex distribution of hepatitis $C$ virus patients, Yemen

\begin{tabular}{|c|c|c|c|c|c|c|}
\hline \multirow{2}{*}{ Age groups } & \multicolumn{2}{|c|}{ Male } & \multicolumn{2}{|c|}{ Female } & \multicolumn{2}{|c|}{ Total } \\
\hline & No. & $\%$ & No. & $\%$ & No. & $\%$ \\
\hline$<20$ years & 4 & 1.4 & 0 & 0 & 4 & 0.8 \\
\hline $20-29$ years & 32 & 11 & 6 & 2.9 & 38 & 7.6 \\
\hline $30-39$ years & 46 & 15.8 & 37 & 17.6 & 83 & 16.5 \\
\hline 40 - 49 years & 96 & 32.9 & 101 & 48 & 197 & 39 \\
\hline 50 - 59 years & 78 & 26.7 & 54 & 25.7 & 132 & 26.3 \\
\hline$\geq 60$ years & 36 & 12.3 & 12 & 5.7 & 48 & 9.6 \\
\hline Total & 292 & 58.2 & 210 & 41.8 & 502 & 100 \\
\hline Mean age & \multicolumn{2}{|c|}{44.8 years } & \multicolumn{2}{|c|}{44.8 years } & \multicolumn{2}{|c|}{44.8 years } \\
\hline S D & \multicolumn{2}{|c|}{12.1 years } & \multicolumn{2}{|c|}{8.4 years } & \multicolumn{2}{|c|}{10.7 years } \\
\hline Min & \multicolumn{2}{|c|}{3 years } & \multicolumn{2}{|c|}{25 years } & \multicolumn{2}{|c|}{3 years } \\
\hline Max & \multicolumn{2}{|c|}{76 years } & \multicolumn{2}{|c|}{65 years } & \multicolumn{2}{|c|}{76 years } \\
\hline Median & \multicolumn{2}{|c|}{46 years } & \multicolumn{2}{|c|}{45 years } & \multicolumn{2}{|c|}{46 years } \\
\hline
\end{tabular}

The study was approved by the Ethics Committee of our university and informed consent was obtained from all study participants.

\section{RESULTS}

Table 1 shows the age and the sex distribution of our hepatitis $C$ virus patients, their age ranged from 3 to 76 years, with the mean age \pm SD for total equal to $44.8 \pm 10.7$ years. Males counted $292(58.2 \%)$ and females were 210 (41.8\%). The genotype distribution in $502 \mathrm{HCV}$-positive patients is shown in Table 2. Overall, HCV genotype 4 was the most predominant genotype $(63.7 \%)$ followed by genotype $1 \mathrm{a}$ and $1 \mathrm{~b}(26.9 \%)$ and $3 \mathrm{a}(7.6 \%)$. Differences in genotype distribution were statistically significant $(p$ $<0.5$ ). Distribution of genotype 4 was roughly similar among males (64.3\%) and females (62.9\%). Also distribution of types $1 \mathrm{a}$ and $1 \mathrm{~b}$ was roughly similar among males (26\%) and females (28.1\%), while type 3a was more commonly seen among males $(2.4 \%)(p<0.5)$ (Table 2$)$.

\section{DISCUSSION}

Understanding of the geographic distribution of common genotypes requires detailed knowledge about the routes of transmission, prevalence of $\mathrm{HCV}$ in general population and in the various high risk groups, phylogenic evolution of types and subtypes over a long period, and also for $\mathrm{HCV}$ medical treatment response, treatment duration and the dose of ribavirin $(7,13)$. Unfortunately, there is little information available on these topics, particularly from Middle East countries and more specifically from Yemen.

Table 2. The prevalence of different HCV genotyping among our HCV patients, Yemen

\begin{tabular}{llllllll}
\hline Genotypes & \multicolumn{2}{l}{ Male $\mathrm{n}=\mathbf{2 9 2}$} & \multicolumn{2}{c}{ Female $\mathrm{n}=\mathbf{2 1 0}$} & \multicolumn{2}{c}{ Total $\mathrm{n}=\mathbf{5 0 2}$} & P value \\
& NO & $\%$ & NO & $\%$ & NO & $\%$ & \\
\hline Genotype 1a +1b & 76 & 26 & 59 & 28.1 & 135 & 26.9 & NS \\
Genotype 2a & 21 & 7.2 & 17 & 8.1 & 38 & 7.6 & NS \\
Genotype 3a & 7 & 2.4 & 2 & 0.95 & 9 & 1.8 & $<0.05$ \\
Genotype 4 & 188 & 64.3 & 132 & 62.9 & 320 & 63.7 & NS \\
Genotype 5 & 0 & 0 & 0 & 0 & 0 & 0 & NS \\
Genotype 6 & 0 & 0 & 0 & 0 & 0 & 0 & NS \\
\hline
\end{tabular}

NS=Non-significant $>0.05$ 
Studies suggest that infections caused by different HCV subtypes may have different clinical outcome and that some subtypes are associated more frequently with advanced liver disease and hepatocellular carcinoma (HCC) $(23,24)$. This is the first published study to report on the genotyping of HCV in Yemen of HCV-positive patients.

The results show that HCV genotype 4 is the predominant genotype $(63.7 \%)$ among Yemeni patients followed by $1 \mathrm{a}$ and $1 \mathrm{~b}(26.9 \%)$ and $2 \mathrm{a}(7.6 \%)$, while genotype $3 \mathrm{a}$ was rarely found $(1.8 \%)$. HCV genotype 4 is the predominant genotype among males and females. There is lack of comprehensive data on the distribution of HCV genotypes in Middle East countries, particularly in the Yemen; however there are few studies which have reported high prevalence of genotype 4 in these countries $(15,16,25,26)$. Genotype 4 is also predominant in Egyptian patients as reported by Ray et al. (27) and Sievert et al. (5) as a most common genotype in Egypt.

The presence of other genotypes such as $1 \mathrm{a}$ and 4 among Yemeni patients can be attributed to many factors. These include the transfer of large number of Yemeni to for works and medication to Middle East countries in which, genotype 4 is predominant in Egypt, Saudi Arabia, 4 and 1 in Kuwait and Syria, and genotype 1 in Lebanon, Iraq and Iran $(5,13-17,27)$.

The infection with genotypes $1 \mathrm{a}$ and 4 may be considered a risk factor for the induction of neuoncoprotein over expression and subsequent development of hepatocellular carcinoma $(5,28)$. The presence of other genotypes such as $2 \mathrm{a}$, and $1 \mathrm{~b}$ among Yemeni patients can be attributed to many factors. These include the transfer of large number of Yemeni to Arabic neighbor countries and to other African and Asian countries and participated in contract infections from their.

The importance of HCV genotyping has considerably increased in the last few years. It has been used to study worldwide and local molecular epidemiology of HCV, and to trace sources of HCV infection in risk groups. Typing has also been used to study relationships between type/ subtype and the clinical status, pathogenesis and/or outcome of disease. The major area of clinical application of HCV genotyping has been in the study of the significance of types/subtypes, in response to antiviral treatment of $\mathrm{HCV}$ infection with interferon and ribavirin, as well as the identification of patients with mixed infections. It has also been a useful application in vaccine research and development $(24,29)$.

\section{REFERENCES}

1. Lavanchy $D$. The global burden of hepatitis C. Liver Int 2009, 29(1):74-81.

2. Ghany MG. Diagnosis, management, and treatment of hepatitis C: An update. Hepatology 2009, 49(4): 1335-74.

3. Choo QL, Kuo G, Weiner AJ, et al. Isolation of a CDNA clone derived from a blood borne non- $A$, non- $B$ hepatitis genome. Science 1989, 244(4902): 359-62.

4. Tokita $H$, Okamoto $H$, Luengrojanakul $P$, et al. Hepatitis $C$ virus variants from Thailand classifiable into five novel genotypes in the sixth (6b), seventh $(7 c, 7 d)$ and ninth (9b, 9c) major genetic groups. J. Gen. Virol 1995, 76(Pt 9): 2329-35.

5. Sievert W, Altraif I, Razavi HA, et al A systematic review of hepatitis $C$ virus epidemiology in Asia, Australia and Egypt. Liver International.2011; 31(supplement 2):61-80.

6. Zein NN. Clinical significance of hepatitis C virus genotypes. Clin. Microbiol Rev 2000, 13(2): 223-35.

7. John AK, Al-Kaabi S, John A, et al. Audit of state-funded antiviral treatment for chronic hepatitis C in Qatar. Eastern Mediterranean Health Journal 2010; 16(11):1121-7.

8. Hnatyszyn HJ Chronic hepatitis $C$ and genotyping: the clinical significance of determining HCV genotypes. Antivir Ther 2005, 10(1):1-11.

9. Alter MJ. Epidemiology of hepatitis C virus infection. World Journal of Gastroenterology 2007; 13(17):2436-41.

10. Gish RG, Lua JYN. Hepatitis C virus: eight years old. Viral Hep Rev 1997, 3: 17-37.

11. Brass V, Moradpour D, Blum HE. Molecular Virology of Hepatitis C Virus (HCV). Int J Med Sci 2006, 3(2): 29-34.

12. Antaki N, Craxi A, Kamal S, et al. The neglected hepatitis $C$ virus genotypes 4, 5 and 6: an international consensus report. Liver International 2010; 30(3):342-55.

13. Zali MR, Mayumi M, Rouf M, et al. Hepatitis C virus genotypes in the Islamic Republic of Iran: a preliminary study. Eastern Mediterr. Health J 2000, 6: 372-7.

14. Pacsa AS, Al-Mufti S, Chugh TD, Said-Adi G. Genotypes of Hepatitis C virus in Kuwait. Med. Principles Pract 2001, 10: 55-7.

15. Osaba AO. Hepatitis C virus genotypes in Saudi Arabia. Saudi Med 2002. J, 23(1): 7-12.

16. Marie Mohammed Ali M. Genotyping of Hepatitis $C$ virus $(\mathrm{HCV})$ in infected patients from Saudi Arabia. African Journal of Microbiology Research 2011, 5(16): 2388-2390.

17. Azhar El, Jamjoom GA, Al-Ghamdi AK, et al. Hepatitis C virus infection among patients on hemodialysis in Jeddah: a single center experience. Saudi Journal of Kidney Diseases and Transplantation 2011; 14(1):84-9. 
18. Sallam TA et al. Prevalence of blood-borne viral hepatitis in different community in Yemen. Epidemiology and Infection, 2003, 131(1):771-5.

19. Al-Waleedi A.A. and Y.S. Khader. Prevalence of hepatitis $B$ and $C$ infections and associated factors among blood donors in Aden city, Yemen. EMHJ 2012; 18(6): 1-7.

20. Haidar NA. Prevalence of hepatitis $B$ and hepatitis $C$ in blood donors and high risk groups in Hajjah, Yemen Republic. Saudi Medical Journal, 2002, 23(9):1090-4.

21. Selm SB. Prevalence of hepatitis $C$ virus infection among hemodialysis patients in a single center in Yemen. Saudi $J$ Kidney Dis Transpl 2010; 21(6):1165-8

22. Daw M A and Dau Aghnaya A. Hepatitis C Virus in Arab World: A State of Concern. Scientific World Journal 2012; 2012:71-9.

23. MCHutchison JG, Gordon SC, Schiff ER, et al. Interferon alfa-2b alone or in combination with ribavirin as initial treatment for chronic hepatitis C. Hepatitis Interventional Therapy Group. N. Eng. J. Med 1998; 339(21): 1485-92.

24. Alfaresi MS. Prevalence of hepatitis C virus (HCV) genotypes among positive UAE patients. Molecular Biology Reports 2011; 38(4):2719-22.
25. Bdour S. Hepatitis C virus infection in Jordanian hemodialysis units, serological diagnosis and genotyping. J. Med. Microbiol 2002, 51(8):700-4.

26. Al Balwi MA. Prevalence of mixed hepatitis $C$ virus (HCV) genotypes among recently diagnosed dialysis patients with HCV infection. Saudi Journal of Kidney Diseases and Transplantation 2011; 22(4):712-6.

27. Ray SC, Arthur RR, Carella A, et al. Genetic Epidemiology of hepatitis C throughout Egypt. J. Infect. Dis 2000, 182(3): 239-44.

28. Zekri AR, Bahnassy AA, Shaarawy SM, et al. Hepatitis $C$ virus genotyping in relation to neu-oncoprotein over expression and the development of hepatocellular carcinoma. J. Med. Microbiol 2000, 49(1): 89-95.

29. Hadziyannis SJ, Sette HJ, Morgan TRl. Peginterferonalpha2a and ribavirin combination therapy in chronic hepatitis C: a randomized study of treatment duration and ribavirin dose. Ann Int Med 2004; 140 (5): 346-55. 